\title{
化学情報へのアクセス いかに活用するか
}

\section{How to find chemical information}

\author{
Robert E. Maizell 著 \\ 飯塚 健, 山崎 昶 共訳
}

（東京 学会出版センター 1983年 262p. A 5 判 定価3,000円）

本書は1979年に出版された原著書の翻訳もの で，原著書は現在，米国化学会化学情報部会会長 として活躍中の著者の 20 年以上の経験に基ついて いる。翻訳によるタイム・ラグを埋めるため，訳 者が必要な所に訳注の形で書き添え, 改訂した所 もある。

ご承知のよらに，化学情報の探索ツールは，ど んどん新しく改良されたものが登場してくるが, 一方では古いッールは時代遅れとなり，価值が低 下すると顧られなくなり，やがてすたれてゆく可 能性がある。

本書は, 化学情報源（情報ソース）の発行にウ エイトを置いて，これに実務的にどのようにアプ ローチしたらよいかが記述されている。読書会や 輪読会の利用, 数種の化学関係ニュース誌の講読, SDI の利用, 学位論文や目下進展中の研究情報の 入手, などから Chemical Abstracts の内容, 命名 法, 特許集録範囲, 総説, CA 以外のサービスなど について触れ，さらに近年とみに盛んとなった， コンピュータ利用のオンライン検索システムの説 明までも含めてまとめられている。さらに情報源 としての特許に関しても簡単に概説し, 生命環境 の局面をも包括した，化学関連の安全の問題につ いても論及している。

実用的アプローチを重んじて, 理論の方は最小 限にとどめ，この分野が将来とも発展を続けて行 くのにどのように対応するかといら，確実な基礎
を作ることに力点が置かれている。そのため，で き得る限りいろいろな情報源に対し，その得失(長 所，欠点）に触れている。

本書に採用されているいろいろな資料は，米国 内の読者を第一に想定してまとめてあるが，日本 の化学関係者にとっても大いに参考になるものと 考觉られる。本書の末尾には，五十音順索引，ア ルファベット順索引，日本の情報サービス機関の リストが付いているのも便利である。

全体の構成は下記のと招りである。

1 幾つかの基本的な考光方

2 情報の流孔と伝達のパターン

3 探索の方策

4 現状把握プログラム

5 文書情報の上手な入手法

6 Chemical Abstracts Service

7 CA 以外の抄録, 索引サービス

8 オンライン，オフライン情報検索サービス

9 総説類

10 大辞典・ハンドブーフ

11 特許

12 安全・防災に関する情報

13 物理学性質などのデータ所在探索

14 化学の市場拉よびビジネス情報源

15 プロセス情報 